\title{
Bi-allelic gene targeting in mouse embryonic stem cells
}

\author{
Peri H. Tate and William C. Skarnes* \\ Wellcome Trust Sanger Institute, Morgan Building, Wellcome Trust Genome Campus, Hinxton, \\ Cambridge CB10 1SA, United Kingdom
}

\begin{abstract}
The EUCOMM and KOMP programs have generated targeted conditional alleles in mouse embryonic stem cells for nearly 10,000 genes. The availability of these stem cell resources will greatly accelerate the functional analysis of genes in mice and in cultured cells. We present a method for conditional ablation of genes in ES cells using vectors and targeted clones from the EUCOMM and KOMP conditional resources. Inducible homozygous cells described here provide a precisely controlled experimental system to study gene function in a model cell.
\end{abstract}

\section{Keywords}

Mouse; Genetics; Embryonic stem cells; Pluripotent; Gene targeting; Homologous recombination; Homozygous; Mutation; Conditional mutagenesis; Gene function

\section{Introduction}

\begin{abstract}
The exploitation of mouse and human embryonic stem (ES) cells to elucidate gene function in normal biologic and disease processes is currently under-utilized and has great potential for high impact science and medicine. Unlike most other cell lines, ES cells are normal diploid cells with apparently unlimited proliferative potential [1,2]. The normal state of the mouse ES cell genome is reproducibly and reliably demonstrated by their ability to re-enter normal development and contribute to all somatic tissues and the germline, when returned to a pre-implantation embryo [3]. In addition to the use of ES cells as a model cell for basic cell biologic processes, ES cells have the capacity to differentiate into many different cell types in vitro. Tremendous progress has been made in defining culture conditions that promote the differentiation of mouse and human stem cells along specific lineages [4,5]. Furthermore, undifferentiated and differentiated ES cells can be grown in sufficient numbers for carrying out many genomic assays such as expression profiling, mass spectrometry and epigenetic profiling. Thus, ES cells provide an excellent model system for the identification of genes and genetic pathways required for basic cellular and developmental functions.
\end{abstract}

The availability of an annotated mouse genome sequence [6] has dramatically changed how gene targeting experiments are conducted and their efficiency in several respects. The availability of annotated genome sequence provides gene structures which are an essential frame work on which to design the optimum targeted allele. The genome sequence has also facilitated the ability to construct targeting vectors by homologous recombination in Escherichia coli (recombineering) in place of conventional restriction-ligation methods [7-9]. This innovation offers several advantages over the previous methods. First, constructs can be generated with nucleotide precision and therefore the design of vectors is not

(C) 2011 Elsevier Inc. All rights reserved.

*Corresponding author. skarnes@ sanger.ac.uk (W.C. Skarnes).. 
constrained by the convenience of relevant restriction sites. Second, these methods work with BAC clones [10] and they enable subcloning (retrieval) of the targeting vector homology arms from the BAC as well as insertion of sequences [11,12]. Finally, these methods have been developed to the point where targeting vectors can be constructed in 96 well plates in parallel with high efficiency [13].

To support and stimulate progress towards the genetic analysis of all mammalian genes, large scale gene knock-out consortia have been established with the goal of generating a complete resource of heterozygous reporter-tagged mutations in C57BL/6 mouse embryonic stem cells [14-16]. The four contributors to this resource are the European Conditional Mouse Mutagenesis Programme (EUCOMM; www.eucomm.org), the NIH-sponsored Knock-out Mouse Programme (KOMP; www.knockoutmouse.org), the Canadian North American Conditional Mouse Mutagenesis Project (NorCOMM; www.norcomm.org), and the Texas Institute for Genomic Research (TIGM; www.tigm.org). By 2011, the projected combined output of these pipelines will establish heterozygous conditional mutations in 13,000 genes (8000 EUCOMM and 5000 KOMP); deletion alleles in 4000 genes ( 3500 KOMP and 500 NorCOMM); and random null or conditional gene trap mutations in 12,000 and 7000 genes by TIGM and EUCOMM, respectively. A common web portal providing access to these resources has been established (www.knockoutmouse.org [17]; with links to designated repositories for ordering vectors, ES cell clones and mice (see article 11).

The majority of the IKMC targeted ES cell resource was generated using the knockout-first approach [18], a strategy that combines the advantages of both a reporter-tagged and a conditional mutation (Fig. 1). In contrast to standard conditional designs, the initial unmodified allele is predicted to generate a null allele through splicing to a lacZ trapping element contained in the targeting cassette. The trapping cassettes include the mouse En2 splice acceptor and the SV40 polyadenylation sequences, signals that have proven to be highly effective in creating null alleles in mice $[19,20]$. The knockout-first allele can be readily modified in ES cells or in crosses to transgenic Flp and Cre mice [21]. A conditional allele is generated by removal of the gene trap cassette by Flp recombinase which reverts the mutation to wild-type, leaving $\operatorname{lox} P$ sites on either side of a critical exon. Subsequent exposure to Cre deletes the critical exon to induce a frame-shift mutation and trigger nonsense-mediated decay of the mutant transcript.

In this article, we describe how the EUCOMM and KOMP conditional resources can be exploited to generate inducible homozygous mutations for functional analysis of genes in mouse embryonic stem cells. This strategy should be broadly applicable to functional analysis of genes in other mammalian cell systems such as rat and human pluripotent stem cells [2,22-25].

\section{Serial targeting strategy}

Genetic screens in cultured cells are presently hampered by the challenges of generating homozygous mutant cells. Bi-allelic mutations can be accomplished in a variety of ways. Most commonly, bi-allelic mutations are generated by serially performing two cycles of gene targeting to knockout both alleles, either by using two vectors with different selectable markers [26] or by re-cycling the vector [27]. Another approach takes advantage of spontaneous loss of heterozygosity ( $\mathrm{LOH}$ ) which can generate cells with an increased dosage of a neomycin resistance gene which, in some circumstances, can be selectively isolated [28,29]. However, these methods generate constitutive mutations and are not applicable to genes essential for cell viability, growth, and pluripotency. Therefore, inducible gene ablation strategies are needed. Furthermore, such an approach is useful to 
study molecular and physiologic changes in cells over time following the removal of gene activity, for example, by expression profiling.

Taking advantage of the wealth of EUCOMM/KOMP targeting vectors and targeted ES cell clones, we developed a serial targeting strategy for the generation of homozygous conditional mutations (Fig. 1). Heterozygous KO-first clones from the EUCOMM/KOMP resources are transiently exposed to Flp recombinase to generate a conditional allele. For targeted loci that express the lacZ reporter, removal of the trapping cassette by Flp can be easily monitored by the loss of $\beta$-galactosidase expression. Reverted G418-sensitive cells are then electroporated with $\mathrm{KO}$-first targeting vector and desired clones that contain both the conditional and KO-first alleles are identified by PCR genotyping. Finally, ligandinducible Cre [30] is introduced into cells using a published, high-efficiency Rosa26 targeting construct [31]. Elimination of gene function in homozygous clones is dependent on the activation of Cre recombinase in cells by treatment with the drug tamoxifen. The effect of gene ablation can thus be assayed in undifferentiated ES cells or at any time following differentiation without incurring any premature selective disadvantage prior to induction of homozygosity.

\section{Methods}

\subsection{Ordering targeted cells from the EUCOMM/KOMP resource}

The availability of knockout-first alleles for genes of interest can be found on the IKMC web portal (www.knockoutmouse.org/mart-search). If successfully targeted, vectors and ES cell clones are available upon request by following the order links on the summary page (see article 11). In addition, fully annotated nucleotide sequences of the targeting vector and the targeted allele can be downloaded in GenBank format. By way of example, we describe the generation of homozygous conditional ES cells for the Chd4 gene, a component of the nucleosome remodeling deacetylase (NuRD) complex highly expressed in embryonic stem cells. Conditional mutagenesis in mice has shown a critical role for Chd4 in T cell development [32], however, the function of Chd4 in the early embryo has not been addressed.

Sixteen correctly targeted clones are available from the EUCOMM repository (Fig. 2), of which thirteen are knockout-first alleles. Homologous recombination events often occur between the selection cassette (neo) and the $3^{\prime}$ loxP site. In the case of $C h d 4,3$ clones lost the the $3^{\prime} \operatorname{lox} P$ site and thus their conditional potential. In extreme cases, such as the Kif6 gene, none of the correctly targeted clones retain the $3^{\prime} l o x P$ site. Due to the highthroughput nature of the EUCOMM/KOMP pipelines, targeted clones are genotyped by long-range PCR, usually across the $3^{\prime}$ homology arm. The amplified products are sequenced to confirm the presence (or absence) of the $3^{\prime}$ lox $P$ site. Because long-range PCR is not quantitative, some clones may be mixed. For this reason we recommend ordering at least 2 knockout-first clones from the resource. Ideally, these clones should be validated by Southern blot. However, for this application, additional rounds of targeting and sub-cloning ensure the homozygous cells are clonally pure.

\subsection{Feeder-free culture of $\mathrm{C} 57 \mathrm{BL} / 6 \mathrm{~N}$ targeted clones}

Knockout-first clones from the EUCOMM/KOMP resource are generated from electroporations of JM8 cells, an ES cell line from the C57BL/6N sub-strain of mice [33]. JM8 ES cells readily adapt to feeder-free culture and can be grown on gelatin in the presence of LIF in either standard serum-containing medium or in chemically-defined serum-free medium. The absence of feeders is ideal for visualizing cellular phenotypes and for biochemical experiments. 
3.2.1. Materials-ES cell medium (M10G) is prepared by adding the following to $500 \mathrm{ml}$ KNOCKOUT DMEM (Invitrogen 10829-018): $50 \mathrm{ml}$ FBS (Invitrogen), $5 \mathrm{ml}$ L-glutamine (100×; Invitrogen 25030-024), $5 \mathrm{ml} 100 \times \beta$-mercaptoethanol (Sigma M7522; $360 \mu \mathrm{l}$ in 500 $\mathrm{ml}$ PBS, filter-sterilized), $5 \mathrm{ml}$ PEN STREP (100×; Invitrogen 15140-122) and LIF (ESGRO; Millipore ESG1107, dilute as directed). Medium is stored at $4{ }^{\circ} \mathrm{C}$ and discarded after 2 weeks. Trypsin solution is prepared by adding $0.1 \mathrm{~g}$ EDTA (Sigma E6511) and $0.5 \mathrm{~g}$ D-glucose (Sigma G7528) to $500 \mathrm{ml} \mathrm{PBS,} \mathrm{filter} \mathrm{sterilized,} \mathrm{then} \mathrm{adding} 5 \mathrm{ml}$ chicken serum

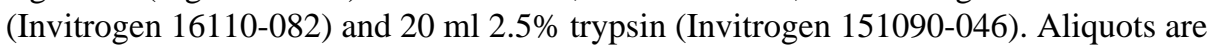
stored at $-20^{\circ} \mathrm{C}$. Gelatin $(0.1 \%$ solution) is prepared by adding $25 \mathrm{ml} 2 \%$ gelatin (Sigma G1393) to $500 \mathrm{ml}$ PBS. Freezing medium is made fresh before use by adding dimethylsulfoxide (DMSO; Sigma D2650) to M10G medium to a final concentration of $10 \%(\mathrm{v} / \mathrm{v})$ and filter sterilized.

3.2.2. Methods-Before starting, pre-warm M10G, trypsin and PBS in a $37^{\circ} \mathrm{C}$ water bath. To gelatinize tissue culture dishes or flasks, add $0.1 \%$ gelatin solution to cover the surface and aspirate (no incubation is required). To thaw cells from a frozen vial, warm the tube in your hand and transfer the contents into $10 \mathrm{ml}$ containing M10G medium. Spin the cells $(1000 \times g)$ for $3 \mathrm{~min}$, aspirate, and resuspend gently in M10G. Transfer the cell suspension to appropriate-sized gelatinized well or dish. As a guide, JM8 cells are growing optimally when cells will reach confluence in $2 \mathrm{~d}$ after passing the cells at a 1:6 dilution. Lower dilutions may be needed initially after thawing cells and during expansion. We recommend seeding the cells at different dilutions (between 1:3 and 1:6) and to carry on with the cells that attain confluence in $2 \mathrm{~d}$.

1. Aspirate media from a near-confluent dish or flask and wash the cells two times with pre-warmed PBS.

2. Add pre-warmed trypsin, rock dish to cover all cells and incubate at $37^{\circ} \mathrm{C}$ for $5-7$ min. While cells are incubating, coat dishes with $0.1 \%$ gelatin, aspirate.

3. Add 5-10 volumes of M10G medium to inactivate the trypsin. Pipette up and down gently 3-4 times to disperse the cells. Transfer 1/6th of cell suspension to each dish containing M10G medium. When expanding to larger dishes, adjust dilution of cells proportional to surface area. Incubate plates in a $37{ }^{\circ} \mathrm{C} / 5 \% \mathrm{CO}_{2}$ incubator.

4. Change medium the following day and repeat process on day 2 . If the cells have not reached confluence in $2 \mathrm{~d}$, pass the cells at a lower dilution or change medium and incubate for one additional day.

5. To freeze cells, trypsinize confluent cultures as above, add 5-10 volumes of M10G medium to inactivate the trypsin and pellet cells by centrifugation $(3 \mathrm{~min}, 1000 \times \mathrm{g}$ ). Aspirate medium and gently resuspend the cell pellet in freezing medium (M10G + $10 \%$ DMSO). Aliquot into cryovials and put them immediately in a $-80{ }^{\circ} \mathrm{C}$ freezer. For long-term storage, transfer cryovials to liquid nitrogen.

\subsection{Generation of the conditional allele with Flp recombinase}

3.3.1. Materials-The trapping cassette is removed by transient expression of Flp recombinase in cells to generate a conditional allele (see Fig. 1). We use the CAGGs-FlpoIRES-puro plasmid [34] which expresses codon-optimized Flp recombinase driven from a strong ES cell promoter. Forty micrograms of circular pCAGGs-Flpo plasmid is used to transfect between 1 and $3 \times 10^{7}$ cells (from $2 \times 10 \mathrm{~cm}$ dishes or $1 \times 75 \mathrm{~cm}^{2}$ flask of nearconfluent cells). Electroporations are carried out using a BioRad Gene Pulser II (equipped with a capacitance extender). The proportion of cells that excise the trapping cassette is greatly enriched (from 10\% to 90\%) by transient selection with puromycin to eliminate cells that have not taken up the Flp expression plasmid. A final concentration of $1 \mu \mathrm{g} / \mathrm{ml}$ 
puromycin (Sigma P8833) is recommended for experiments in JM8 ES cells. For knockoutfirst cells that express the lacZ reporter, the excision of the trapping cassette by Flp recombinase is easily monitored by histochemical staining with X-gal (Fig. 3), but the excision should be confirmed by long-range PCR. If LacZ expression is not detectable, clones must be genotyped by long-range PCR (see Section 3.6). For staining cells with Xgal, prepare $0.1 \mathrm{M}$ phosphate buffer, $\mathrm{pH} 7.3$ by dissolving $3.74 \mathrm{~g} / \mathrm{l}$ sodium phosphate, monobasic (Sigma S9638) and 10.35 g/l sodium phosphate, dibasic (Sigma S9763) in distilled water. Xgal (5-bromo-4-chloro-3-indolyl $\beta$-D-galactoside, Sigma B4252) is dissolved in dimethylformamide (Sigma D4551) at a concentration of $50 \mathrm{mg} / \mathrm{ml}$ and stored in the dark at $-20^{\circ} \mathrm{C}$. Prepare fix, wash and staining solutions as follows:

Fix solution: $0.1 \mathrm{M}$ phosphate buffer (pH 7.3), $5 \mathrm{mM}$ EGTA, $2 \mathrm{mM} \mathrm{MgCl} 2,0.2 \%$ glutaraldehyde (Sigma G7776).

Wash solution: $0.1 \mathrm{M}$ phosphate buffer ( $\mathrm{pH} 7.3), 2 \mathrm{mM} \mathrm{MgCl} 2$.

Staining solution: $0.1 \mathrm{M}$ phosphate buffer ( $\mathrm{pH} 7.3), 2 \mathrm{mM} \mathrm{MgCl} 2,5 \mathrm{mM}$ potassium ferrocyanide (Sigma P9387), $5 \mathrm{mM}$ potassium ferricyanide (Sigma P8131), $1 \mathrm{mg}$ / $\mathrm{ml} \mathrm{X-gal} \mathrm{(filter} \mathrm{before} \mathrm{use} \mathrm{to} \mathrm{avoid} \mathrm{crystal} \mathrm{formation).}$

3.3.2. Methods-One day prior to electroporation, precipitate $40 \mu \mathrm{g}$ pCAGGs-Flpo plasmid (33) with ethanol in an eppendorf tube and spin down the DNA in a microfuge wash the DNA pellet twice in $70 \%$ ethanol and evaporate off the ethanol in a laminar flow hood for 20-30 min. Add $0.1 \mathrm{ml}$ sterile PBS and leave the sample to resuspend overnight in the hood. Change the media on near-confluent ES cell cultures 3-4 h before electroporation. Pre-warm PBS and trypsin in $37{ }^{\circ} \mathrm{C}$ water bath. Room-temperature PBS is also need for washing cells prior to electroporation.

1. Trysinize the cells as described above (Section 3.3.2) and add $20 \mathrm{ml} \mathrm{M} 10 \mathrm{G}$ medium to stop the trypsin. Pellet the cells by centrifugation $(3 \mathrm{~min}, 1000 \times \mathrm{g}$ ) and resuspend the cells in $10 \mathrm{ml}$ room-temperature PBS. Count an aliquot of the cell suspension in a hemocytometer to determine the total cell number. Pellet the cells by centrifugation $(3 \mathrm{~min}, 1000 \times \mathrm{g}$ ) and resuspend the cells in a final volume of 0.7 $\mathrm{ml}$ room-temperature PBS.

2. Set the electroporator to $250 \mathrm{~V} / 500 \mu \mathrm{F}$ (on high capacitance setting using the capacitance extender unit). With a $1 \mathrm{ml}$ pipette, add the cell suspension to the the eppendorf tube containing the pCAGGs-Flpo plasmid, mix and transfer the sample to an electroporation cuvette ( $0.4 \mathrm{~cm}$ gap; BioRad). Electroporate the sample ( 6-7 ms time constant) and let the cells recover for $20 \mathrm{~min}$ in the hood. While waiting, gelatinize three $10 \mathrm{~cm}$ dishes.

3. Remove the cell suspension from the cuvette and add to $10 \mathrm{ml} \mathrm{M} 10 \mathrm{G}$ medium. Plate $5 \times 10^{6}, 2 \times 10^{6}$ and $1 \times 10^{6}$ cells onto gelatinized $10 \mathrm{~cm}$ dishes, adding M10G to a final volume of $10 \mathrm{ml}$. For even plating, mix the cells by gentle pipetting and place in $37{ }^{\circ} \mathrm{C} / 5 \% \mathrm{CO}_{2}$ incubator.

4. Change the medium on all plates the following day. Thirty-six hours postelectroporation, replace the medium with $\mathrm{M} 10 \mathrm{G}$ containing $1 \mu \mathrm{g} / \mathrm{ml}$ puromycin and maintain drug selection for $2 \mathrm{~d}$, changing the medium every day. Withdraw drug selection on $\mathrm{d} 4$ and allow the surviving cells to grow for several days in M10G until colonies are visible, changing the medium every $2 \mathrm{~d}$.

5. When colonies are $\sim 1 \mathrm{~mm}$ in diameter, replace the medium in the dish with $10 \mathrm{ml}$ room-temperature PBS. Using a dissecting microscope, dislodge and pick 24-48 colonies in a volume of $15 \mu \mathrm{l}$ with a $20 \mu \mathrm{l}$ Pipetteman. Dispense each colony into a 
well of a 96-well round bottom plate containing $15 \mu \mathrm{l}$ of trypsin and incubate the plate at $37^{\circ} \mathrm{C}$ for $15 \mathrm{~min}$. Stop the trypsin by adding $170 \mu \mathrm{l} \mathrm{M10G}$, gently pipette up and down five times to disperse the colonies, and transfer the cells to a gelatinized 96-well tissue culture plate.

6. Change the medium every day until most of the wells are nearly confluent (3-4d). Split the clones at a 1:3 dilution onto three gelatinized 96-well plates for X-gal staining, preparation of genomic DNA for genotyping, and expansion of conditional clones. Change the medium every day until confluent (2-3 d).

7. To prepare genomic DNA for genotyping, drain media from one 96-well plate by inversion and blot on paper towels. Lyse cells in $100 \mu 1$ lysis buffer (see Section 3.5.1), incubate at $65^{\circ} \mathrm{C}$ for $4 \mathrm{~h}$, heat inactivate at $90^{\circ} \mathrm{C}$ by placing the plate on the surface of a heating block for $10 \mathrm{~min}$ and store the plate at $-20^{\circ} \mathrm{C}$.

8. To stain for $\beta$-galactosidase, drain the medium from the second 96-well plate and fix cells for $5 \mathrm{~min}$ in $100 \mu \mathrm{l}$ fix solution. Wash the cells twice with $200 \mu \mathrm{l}$ wash solution ( $2 \mathrm{~min}$ ), then add $50 \mu \mathrm{l}$ staining solution to each well and incubate overnight at $37^{\circ} \mathrm{C}$.

9. To expand the clones, trypsinize the clones in the third 96-well plate and seed the cells onto a gelatinized 48 -well plate.

Select clones that are devoid of $\beta$-galactosidase-positive cells for further expansion (or clones that carry only the conditional allele by PCR genotyping). Before proceeding to the next step, it is critical to confirm that the Flp-treated clones are pure and sensitive to both G418 and puromycin. Contamination of revertant clones with G418-resistant and/or puromycin-resistant cells will interfere with the targeting second allele and/or introduction of CreER ${ }^{\mathrm{T} 2}$, respectively. Expand the clones from 48- to 12- to 6-well plates in triplicate in M10G, M10G + $150 \mu \mathrm{g}$ (active)/ml G418 (Geneticin, Invitrogen 11811-023), and M10G + $1 \mu \mathrm{g} / \mathrm{ml}$ puromycin. Only cells cultured in M10G should survive. To freeze expanded clones from 6-well plates, trypsinize each well in a volume of $0.5 \mathrm{ml}$ for $5-7 \mathrm{~min}$ at $37^{\circ} \mathrm{C}$, stop the reaction with $4.5 \mathrm{ml} \mathrm{M} 10 \mathrm{G}$ and pellet the cells by centrifugation $(3 \mathrm{~min}, 1000 \times g)$.

Resuspend the cell pellet in $1 \mathrm{ml}$ M10G medium containing $10 \%(\mathrm{v} / \mathrm{v})$ DMSO and freeze 2 $\times 0.5 \mathrm{ml}$ aliquots in cryovials. Each aliquot can be thawed onto 6-well gelatinized dishes and should reach confluence in 2 days.

Note: If none of the Flp-treated clones are pure, sub-cloning is required. To obtain subclones, seed 2000 cells onto a gelatinized $10 \mathrm{~cm}$ dish and culture in M10G until colonies are visible. Repeat the process above from step 5 .

\subsection{Targeting the 2 nd allele in Flp-reverted clones}

3.4.1. Materials-Clonally pure, Flp-treated cells isolated above are electroporated with the knock-out first targeting vector obtained from the repository to generate bi-allelic targeting events (conditional/knockout-first). Typically, 15-25 $\mu \mathrm{g}$ of linearized vector DNA is used in electroporations of $2-3 \times 10^{7}$ cells $\left(2 \times 10 \mathrm{~cm}\right.$ dishes or $1 \times 75 \mathrm{~cm}^{2}$ flask). Electroporations are carried out with a BioRad Gene Pulser using a high voltage, low capacitance setting $(800 \mathrm{kV}, 3 \mu \mathrm{F}) .150 \mu \mathrm{g}$ (active)/ml G418 (Geneticin, Invitrogen 11811-023) is recommended for gene targeting experiments in JM8 ES cells. As controls, untransfected cells are cultured in G418-containing medium and in puromycin-containing medium to check for low-level contamination of the cultures with G418-resistant and/or puromycin-resistant cells. If colonies appear on the control plates, the Flp-treated clone(s) may require a second round of sub-cloning (see Note for Section 3.3.2). 
The knockout-first targeting construct from the repository can be verified by sequencing, or more simply, by comparing a restriction digest of the plasmid to the expected fragment sizes of vector sequence in silico. We use DNASTAR software to upload the vector sequence (Genbank format) and generate a virtual gel for one or more common 6-cutter restriction enzymes. Knockout-first targeting vectors clones are supplied in the DH10B strain of $E$. coli. It is important to check the antibiotic resistance marker in the map or annotated sequence of the vector as a number of different antibiotic-resistance genes were used in their construction. Each targeting vector contains a unique AsiSI site for linearizing the vector prior to electroporation.

\subsubsection{Methods}

3.4.2.1. Preparation of the targeting vector for electroporation: Vector DNA prepared from bacterial cultures on Qiagen columns is suitable for electroporation of ES cells. Allow two days for preparing the DNA for electroporation.

1. In an eppendorf tube, digest 5-15 $\mu$ g vector DNA with AsiSI (New England Biolabs) and run $100 \mathrm{ng}$ on a gel to check that the digestion is complete (if not, add additional enzyme and incubate for longer).

2. Adjust the concentration of $\mathrm{NaCl}$ to $0.1 \mathrm{M}$ and add 2 volumes of ethanol. Mix well by inversion and precipitate the linearized vector DNA on ice for $5 \mathrm{~min}$.

3. Spin in microfuge for $10 \mathrm{~min}$. Wash the DNA pellet twice with $70 \%$ ethanol and remove excess ethanol after the second wash.

4. Allow the DNA pellet to air dry in laminar flow hood for 20-40 min. Resuspend the semi-dry pellet in $0.1 \mathrm{ml}$ sterile PBS and allow the sample to dissolve overnight in the hood.

3.4.2.2. Electroporation of ES cells: Change the media on near-confluent ES cell cultures 3-4 h before electroporation. Pre-warm PBS and trypsin in $37^{\circ} \mathrm{C}$ water bath. Roomtemperature PBS is also need for washing cells prior to electroporation.

1. Trysinize dishes of confluent cells as described above (Section 3.3.2). After adding M10G to stop the trypsin, pellet cells by centrifugation $(3 \mathrm{~min}, 1000 \times \mathrm{g}$ ) and resuspend in $20 \mathrm{ml}$ room-temperature PBS. Count cells in a hemocytometer. As a control, seed two gelatinized $10 \mathrm{~cm}$ dishes with $5 \times 10^{6}$ cells in $10 \mathrm{ml} \mathrm{M} 10 \mathrm{G}$ medium and place in $37{ }^{\circ} \mathrm{C} / 5 \% \mathrm{CO}_{2}$ incubator. Pellet the remaining cells by centrifugation $(3 \mathrm{~min}, 1000 \times g$ ) and resuspend the cells in a final volume of $0.7 \mathrm{ml}$ room-temperature PBS.

2. Set the electroporator to $800 \mathrm{~V} / 3 \mu \mathrm{F}$. With a $1 \mathrm{ml}$ pipette, add the cell suspension to the linearized vector in the eppendorf tube, mix and transfer the sample to an electroporation cuvette (0.4 cm gap; BioRad). Electroporate the sample $(\sim 0.04 \mathrm{~ms}$ time constant) and allow the cells recover for $20 \mathrm{~min}$ in the hood. While waiting, gelatinize three $10 \mathrm{~cm}$ dishes.

3. Remove the cell suspension from the cuvette and add to $10 \mathrm{ml} \mathrm{M} 10 \mathrm{G}$ medium. Plate $1 \times 10^{7}, 5 \times 10^{6}, 2 \times 10^{6}$ cells onto gelatinized $10 \mathrm{~cm}$ dishes, adding M10G to a final volume of $10 \mathrm{ml}$. For even plating, gently mix the cells by pipetting and place in a $37^{\circ} \mathrm{C} / 5 \% \mathrm{CO}_{2}$ incubator.

4. Begin drug selection the following day. The experimental plates and one control plate are cultured in M10G $+150 \mu \mathrm{g}$ (active)/ml G418. The second control plate is cultured in $\mathrm{M} 10 \mathrm{G}+1 \mathrm{mg} / \mathrm{ml}$ puromycin. The medium is changed every day for the 
first $4 \mathrm{~d}$ of selection and then every other day until colonies are visible by eye. No colonies should appear on the control plates (see Note for Section 3.3.2 above).

When colonies are $\sim 1 \mathrm{~mm}$ in diameter, pick 48-96 colonies and culture in gelatinized 96well plates as described in the previous section. Since all clones will be screened by longrange PCR, we recommend freezing a copy of cells until genotyping is completed. To freeze clones in a 96-well plate, wash cells twice with pre-warmed PBS and add $25 \mathrm{ml}$ trypsin. Incubate the plate at $37{ }^{\circ} \mathrm{C}$ for 5-7 min and stop the trypsin with $125 \mu \mathrm{l}$ filter-sterilized M10G medium containing 12\% DMSO (v/v). Disperse cells by gentle pipetting and store the plate in a $-80{ }^{\circ} \mathrm{C}$ freezer.

\subsection{Genotyping clones by long-range PCR}

Following the second round of gene targeting, long-range PCR genotyping is used to identify ES cell clones which have targeted mutations in both copies of the gene of interest one conditional allele and one knock-out first allele. The genotyping strategy outlined in Fig. 4 is designed to achieve the following objectives: (1) independently assay for the presence of both the conditional and knock-out first alleles and (2) confirm targeting at the desired locus (as opposed to random vector integration). Finally, to conclusively demonstrate the presence of both modified alleles in individual cells it is advisable to repeat this genotyping assay again following the final step of the serial targeting process (introduction of CreER ${ }^{\mathrm{T} 2}$ at the Rosa26 locus) and confirm that subclones retain both alleles.

3.5.1. Materials-Genomic DNA for genotyping is prepared by direct lysis of cells in the following buffer:

Cell lysis buffer: $50 \mathrm{mM} \mathrm{KCl}, 10 \mathrm{mM}$ Tris- $\mathrm{HCl} \mathrm{pH} \mathrm{8.3,} 2 \mathrm{mM} \mathrm{MgCl}_{2}, 0.45 \%$

NP40 (Igepal CA-630, Sigma I8896), 0.45\% Tween 20 (Sigma P9416), adding proteinase K powder (Sigma P6556) to $1 \mu \mathrm{g} / \mathrm{ml}$ immediately prior to use.

Desalted 25-mer oligonucleotides (Sigma, 20 pmol synthesis) are used for long-range PCR. The sequence of vector-specific primers are as follows:

\section{En2R: 5' - TGTTAGTCCCAACCCCTTCCTCC}

\section{NF: 5' - GGTACCGCGTCGAGAAGTTCCTATT}

\section{LR: 5'-TGAACTGATGGCGAGCTCAGACCAT}

Gene-specific primers for long-range PCR are automatically generated from genomic sequence outside of the $5^{\prime}$ (GF3/4) and 3' (GR3/4) homology arms for each targeted allele. These sequences can be found by following the 'Design ID' link for targeted ES cell clones (see Fig. 2). LR-PCR primers used for the genotyping the $C h d 4$ targeted allele are:

\begin{tabular}{ll}
\hline GF3 & CACATTCATTGCAAGGTCGGTATCTTCTC \\
GF4 & GAGAGGCAGCATGCAGTAGCCTAGTGAG \\
GR3 & CATCTGTGCCATGGTGCGCATGTGTGCAG \\
GR4 & CACTCTTCTCTTACCATTGAAGCGATC \\
\hline
\end{tabular}

We have obtained satisfactory results with a number of different long range DNA amplification systems. Here we describe the use of the SequalPrep Long-Range PCR kit (Invitrogen A10498). 
3.5.2. Methods-For long-range PCR analysis, 96-well plates of cell lysates (from step 7, Section 3.3.2) are thawed and placed on ice. Pipette the contents of each well up and down a few times using a multichannel pipette. Lysates are diluted 1:10-1:20 in $10 \mathrm{mM}$ Tris $\mathrm{pH} 8$ in a 96-well reaction plate for PCR. Diluted lysates can be stored indefinitely at $-20{ }^{\circ} \mathrm{C}$. To set up the PCR reaction, combine the following:

$1 \mu \mathrm{l}$ of diluted cell lysate.

$9 \mu 1$ primer mix $(0.4 \mu 120 \mathrm{pmol} / \mu \mathrm{l}$ of each primer, $8.2 \mu \mathrm{l}$ PCR-grade water).

$10 \mu 1$ SequalPrep master mix ( $2 \mu 1$ 10X reaction buffer including dNTPs, $0.2 \mu 1$

$100 \%$ DMSO, $1 \mu 15 \mathrm{X}$ enhancer $\mathrm{A}, 1 \mu \mathrm{l}$ X enhancer B, $0.3 \mu 1$ sequalprep enzyme, $5.5 \mu \mathrm{l}$ PCR-grade water).

Seal plate with a thermocycler seal, briefly spin the plate in a bench-top centrifuge and amplify the products using the following cycling conditions:

1. $93^{\circ} \mathrm{C}$ for $3 \mathrm{~min}$.

2. 8 cycles: $93{ }^{\circ} \mathrm{C}$ for $15 \mathrm{~s}, 68^{\circ} \mathrm{C}$ for $30 \mathrm{~s}(+10 \mathrm{~s}$ each additional cycle).

3. 25 cycles: $93{ }^{\circ} \mathrm{C}$ for $15 \mathrm{~s}, 60^{\circ} \mathrm{C}$ for $30 \mathrm{~s}, 68^{\circ} \mathrm{C}$ for $6 \min (+10 \mathrm{~s}$ each additional cycle).

4. 7 min extension period at $68{ }^{\circ} \mathrm{C}$.

This protocol has been used successfully in both MJ Research DNA Engine Tetrad and Applied Biosystems Gene Amp PCR System 9700 thermocyclers.

\subsection{Introduction of Cre-ER ${ }^{\mathrm{T} 2}$ into homozygous clones}

3.6.1. Materials-Targeting of the tamoxifen-responsive $\mathrm{CreER}^{\mathrm{T} 2}$ fusion protein to the Rosa26 locus [31] is reliably a very efficient event in mouse ES cells, occurring in $>90 \%$ of drug-selected clones. Consequently, this step can be done on a small scale, with fewer cells (a confluent $25 \mathrm{~cm}^{2}$ flask or $10 \mathrm{~cm}$ dish) and less input vector DNA $(2-5 \mu \mathrm{g})$. The targeting vector is linearized with SfiI (New England Biolabs) for $4 \mathrm{~h}$ at $50{ }^{\circ} \mathrm{C}$ and prepared for electroporation as described in Section 3.4.2 above.

3.6.2. Methods-Expand two homozygous targeted clones and one heterozygous clone to serve as a control. Freeze stock and seed a $25 \mathrm{~cm}^{2}$ flask or $10 \mathrm{~cm}$ dish of each for electroporation. Change the media on near-confluent ES cell cultures 3-4 h before electroporation. Pre-warm PBS and trypsin in $37{ }^{\circ} \mathrm{C}$ water bath. Room-temperature PBS is also need for washing cells prior to electroporation.

1. Trysinize flasks of confluent cells as described above (Section 3.3.2). After adding M10G to stop the trypsin, pellet cells by centrifugation ( $3 \mathrm{~min}, 1000 \times g$ ) and resuspend in $20 \mathrm{ml}$ room-temperature PBS. Count cells in a haemocytometer. Pellet the cells by centrifugation ( $3 \mathrm{~min}, 1000 \times \mathrm{g}$ ) and resuspend in a final volume of 0.7 $\mathrm{ml}$ room-temperature PBS.

2. Set the electroporator to $800 \mathrm{~V} / 3 \mu \mathrm{F}$. With a $1 \mathrm{ml}$ pipette, add the cell suspension to the linearized vector in the eppendorf tube, mix and transfer the sample to an electroporation cuvette (0.4 cm gap; BioRad). Electroporate the sample $(\sim 0.04 \mathrm{~ms}$ time constant) and allow the cells recover for $20 \mathrm{~min}$ in the hood. While waiting, gelatinize two $10 \mathrm{~cm}$ dishes/cell line to be electroporated.

3. Remove the cell suspension from the cuvette and add to $3 \mathrm{ml} \mathrm{M} 10 \mathrm{G}$ medium. Plate 1 and $2 \mathrm{ml}$ of cells onto gelatinized $10 \mathrm{~cm}$ dishes, adding M10G to a final volume 
of $10 \mathrm{ml}$. For even plating, gently mix the cells by pipetting and place in a $37^{\circ} \mathrm{C} /$ $5 \% \mathrm{CO}_{2}$ incubator.

4. Begin drug selection the following day. Plates and are cultured in $\mathrm{M} 10 \mathrm{G}+1 \mu \mathrm{g} / \mathrm{ml}$ puromycin. The medium is changed every day for the first 4 days of selection and then every other day until colonies are visible by eye.

5. When colonies are $\sim 1 \mathrm{~mm}$ in diameter, pick $12-24$ colonies for each of the clones targeted and culture in gelatinzed 96-well plates as described in the previous sections.

Due to the high efficiency of targeting with the Rosa26:CreER ${ }^{\mathrm{T} 2}$ construct we do not find it necessary to confirm homologous recombination in the resulting clones but rather we screen the resulting clones for tamoxifen-responsive Cre activity.

\subsection{Elimination of gene activity with tamoxifen}

3.7.1. Materials-A $1.5 \mathrm{mM}$ stock solution of 4-hydroxy-tamoxifen (Sigma H6278) is prepared by dissolving $10 \mathrm{mg}$ of 4-OHT in $17.2 \mathrm{ml} 99 \%$ ethanol and stored at $4{ }^{\circ} \mathrm{C}$ (or -20 ${ }^{\circ} \mathrm{C}$ for long-term storage).

3.7.2. Methods-To induce gene inactivation by tamoxifen treatment, individual clones are seeded in duplicate gelatinized multi-well dishes at normal passage density. The following day, the media for one set of wells is replaced with M10G medium containing 0.4 $\mu \mathrm{M} 4-\mathrm{OHT}$ and the duplicate wells are replaced with M10G containing an equivalent volume of $99 \%$ ethanol. Twenty-four hours later, the cells should be near confluent.

The Cre-mediated deletion event occurs quite rapidly in the ES cell genome. In our experience deletion of the floxed/critical region is usually complete in the population of cells treated for $24 \mathrm{~h}$ with drug (PT, unpublished data). At this point cells are screened for Cremediated activation of the mutation by short range PCR, inferring correct targeting of $\mathrm{CreER}^{\mathrm{T} 2}$ to the Rosa26 locus in clones that carry the deleted allele. PCR primers are designed to detect a complete deletion of the floxed critical exon. Once OHT-responsive clones are identified, multiple independent clones may be expanded and frozen for further analysis.

For molecular or cellular phenotyping of mutant cells it is important to establish the time frame over which wild-type RNA or full-length protein is eliminated prior to the onset of any change in morphology or growth rate of the cells. In this example, we analyzed tamoxifen-treated and untreated clones by Western blot (Fig. 5). Complete loss of Chd4 protein occurs within 5 days, during which time the cells display no overt phenotype. Shortly thereafter, strong effects on cell morphology and proliferation are observed in homozygous cells compared to non-treated control cells. We are currently examining gene expression changes resulting from inactivation of this critical component of a chromatin remodeling activity important in ES cells [35].

\section{Acknowledgments}

We thank Derek Matthews for assisting us in preparing this manuscript for publication. This work was supported by the Wellcome Trust.

\section{References}

[1]. Evans MJ, Kaufman MH. Nature. 1981; 292:154-156. [PubMed: 7242681]

[2]. Thomson JA, Itskovitz-Eldor J, Shapiro SS, Waknitz MA, Swiergiel JJ, Marshall VS, Jones JM. Science. 1998; 282:1145-1147. [PubMed: 9804556] 
[3]. Bradley A, Evans M, Kaufman MH, Robertson E. Nature. 1984; 309:255-256. [PubMed: 6717601]

[4]. Guan K, Rohwedel J, Wobus AM. Cytotechnology. 1999; 30:211-226. [PubMed: 19003371]

[5]. Murry CE, Keller G. Cell. 2008; 132:661-680. [PubMed: 18295582]

[6]. Waterston RH, Lindblad-Toh K, Birney E, Rogers J, Abril JF, Agarwal P, Agarwala R, Ainscough R, Alexandersson M, et al. Nature. 2002; 420:520-562. [PubMed: 12466850]

[7]. Zhang Y, Buchholz F, Muyrers JP, Stewart AF. Nat. Genet. 1998; 20:123-128. [PubMed: 9771703]

[8]. Muyrers JP, Zhang Y, Testa G, Stewart AF. Nucleic Acids Res. 1999; 27:1555-1557. [PubMed: 10037821]

[9]. Angrand PO, Daigle N, van der Hoeven F, Scholer HR, Stewart AF. Nucleic Acids Res. 1999; 27:e16. [PubMed: 10446259]

[10]. Osoegawa K, Tateno M, Woon PY, Frengen E, Mammoser AG, Catanese JJ, Hayashizaki Y, de Jong PJ. Genome Res. 2000; 10:116-128. [PubMed: 10645956]

[11]. Liu P, Jenkins NA, Copeland NG. Genome Res. 2003; 13:476-484. [PubMed: 12618378]

[12]. Chan W, Costantino N, Li R, Lee SC, Su Q, Melvin D, Court DL, Liu P. Nucleic Acids Res. 2007; 35:e64. [PubMed: 17426124]

[13]. Posner I, Sarov M, Hutchins JR, Hériché JK, Toyoda Y, Pozniakovsky A, Weigl D, Nitzsche A, Hegemann B, Bird AW, Pelletier L, Kittler R, Hua S, Naumann R, Augsburg M, Sykora MM, Hofemeister H, Zhang Y, Nasmyth K, White KP, Dietzel S, Mechtler K, Durbin R, Stewart AF, Peters JM, Buchholz F, Hyman AA. Nat. Methods. 2008; 5:409-415. [PubMed: 18391959]

[14]. Austin CP, Battey JF, Bradley A, Bucan M, Capecchi M, Collins FS, Dove WF, Duyk G, Dymecki S, Eppig JT, et al. Nat. Genet. 2004; 36:921-924. [PubMed: 15340423]

[15]. Auwerx J, Avner P, Baldock R, Ballabio A, Balling R, Barbacid M, Berns A, Bradley A, Brown S, Carmeliet P, et al. Nat. Genet. 2004; 36:925-927. [PubMed: 15340424]

[16]. International Mouse Knockout Consortium. Cell. 2007; 128:9-13. [PubMed: 17218247]

[17]. Ringwald M, Iyer V, Mason JC, Stone KR, Tadepally HD, Kadin JA, Bult CJ, Eppig JT, Oakley DJ, Briois S, Stupka E, Maselli V, Smedley D, Liu S, Hansen J, Baldock R, Hicks GG, Skarnes WC. Nucleic Acids Res. 2010; 6

[18]. Testa G, Schaft J, van der Hoeven F, Glaser S, Anastassiadis K, Zhang Y, Hermann T, Stremmel W, Stewart AF. Genesis. 2004; 38:151-158. [PubMed: 15048813]

[19]. Skarnes WC, Auerbach BA, Joyner AL. Genes Dev. 1992; 6:903-918. [PubMed: 1592261]

[20]. Mitchell KJ, Pinson KI, Kelly OG, Brennan J, Zupicich J, Scherz P, Leighton PA, Goodrich LV, Lu X, Avery BJ, Tate P, Dill K, Pangilinan E, Wakenight P, Tessier-Lavigne M, Skarnes WC. Nat. Genet. 2001; 28:241-249. [PubMed: 11431694]

[21]. Branda CS, Dymecki SM. Dev. Cell. 2004; 6:7-28. [PubMed: 14723844]

[22]. Takahashi K, Tanabe K, Ohnuki M, Narita M, Ichisaka T, Tomoda K, Yamanaka S. Cell. 2007; 131:861-872. [PubMed: 18035408]

[23]. Buehr M, Meek S, Blair K, Yang J, Ure J, Silva J, McLay R, Hall J, Ying QL, Smith A. Cell. 2008; 135:1287-1298. [PubMed: 19109897]

[24]. Li P, Tong C, Mehrian-Shai R, Jia L, Wu N, Yan Y, Maxson RE, Schulze EN, Song H, Hsieh CL, Pera MF, Ying QL. Cell. 2008; 135:1299-1310. [PubMed: 19109898]

[25]. Bu L, Gao X, Jiang X, Chien KR, Wang Z. Cell Res. 2010; 20:379-382. [PubMed: 20142843]

[26]. teRiele H, Maandag ER, Clarkem A, Hooper M, Berns A. Nature. 1990; 348:649-651. [PubMed: 2250720]

[27]. Abuin A, Bradley A. Mol. Cell. Biol. 1996; 16:1851-1856. [PubMed: 8657161]

[28]. Mortensen RM, Conner DA, Chao S, Geisterfer-Lowrance AA, Seidman JG. Mol. Cell. Biol. 1992; 12:2391-2395. [PubMed: 1569957]

[29]. Lefebvre L, Dionne N, Karaskova J, Squire JA, Nagy A. Nat. Genet. 2001; 27:257-258. [PubMed: 11242104]

[30]. Feil R, Brocard J, Mascrez B, LeMeur M, Metzger D, Chambon P. Proc. Natl Acad. Sci. USA. 1996; 93:10887-10890. [PubMed: 8855277] 
[31]. Vooijs M, Jonkers J, Berns A. EMBO Rep. 2001; 2:292-297. [PubMed: 11306549]

[32]. Williams CJ, Naito T, Arco PG, Seavitt JR, Cashman SM, De Souza B, Qi X, Keables P, Von Andrian UH, Georgopoulos K. Immunity. 2004; 6:719-733. [PubMed: 15189737]

[33]. Pettitt SJ, Liang Q, Rairdan XY, Moran JL, Prosser HM, Beier DR, Lloyd KC, Bradley A, Skarnes WC. Nat. Methods. 2009; 6:493-495. [PubMed: 19525957]

[34]. Kranz A, Fu J, Duerschke K, Weidlich S, Naumann R, Stewart AF, Anastassiadis K. Genesis. 2010; 48:512-520. [PubMed: 20506501]

[35]. Kaji K, Caballero IM, MacLeod R, Nichols J, Wilson VA, Hendrich B. Nat. Cell Biol. 2006; 8:285-292. [PubMed: 16462733] 

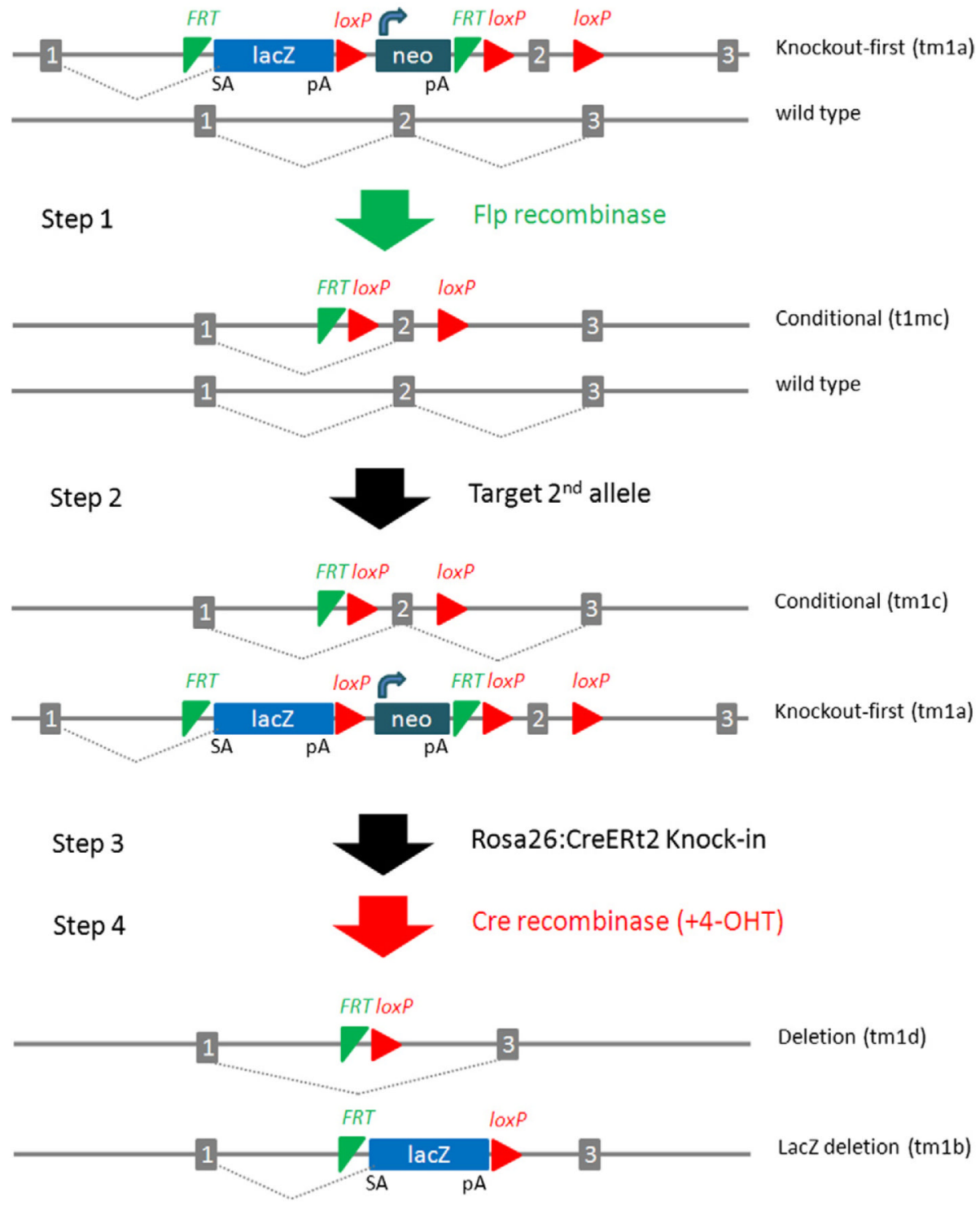

Fig. 1.

Bi-allelic targeting strategy. Step 1: Heterozygous KO-first alleles (tm1a) are converted to conditional alleles (tm1c) by transient expression of Flp recombinase. Step 2: The second allele is targeted by re-cycling the knockout-first targeting vector, generating bi-allelic ES cells that carry a conditional allele (tm1c) and a knockout-first allele (tm1a). Step 3: Inducible Cre-recombinase is introduced into cells by high efficiency targeted insertion into the Rosa26 locus. Step 4: Gene activity is eliminated in undifferentiated or differentiated ES cell cultures through activation of Cre-recombinase with tamoxifen (4-OHT), generating deletion alleles (tm1d and tm1b). 
- IKMC Targeted Products

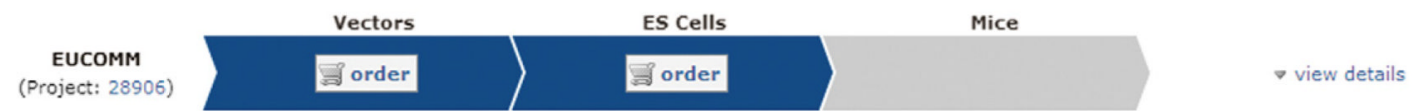

\section{ES Cell Clones}

\begin{tabular}{|l|l|l|}
\hline Design ID & \# Knockout First Clones & \# Targeted Non-Conditional Clones \\
\hline 48412 (Knock Out) & 13 (genbank file | allele image I vector image) & 3 (genbank file I allele image I vector image) \\
\hline
\end{tabular}

\section{Links}

e! view this allele in Ensembl

$\Rightarrow$ view allele details (HTGT)

$\Rightarrow$ view allele details (IKMC)

$\checkmark$ view all available ES cell clones

\section{ES Cell Clones With Conditional Potential}

\begin{tabular}{|c|c|c|c|c|c|c|c|c|}
\hline ES Cell Clone & \multicolumn{2}{|c|}{ Targeting Vector } & ES Cell Strain & ES Cell Line & \multicolumn{2}{|l|}{ Allele } & \multicolumn{2}{|c|}{ QC/Screening Data } \\
\hline EPD0157_4_A09 & \multicolumn{2}{|c|}{ PRPGS00068_A_B04 } & C57BL/6N & JM8.N4 & \multicolumn{2}{|c|}{$\operatorname{tm} 1 \mathrm{a}(\mathrm{EUCOMM}) W \mathrm{tsi}$} & \multicolumn{2}{|c|}{$\nabla$ view data $(\Rightarrow$ about $)$} \\
\hline \multicolumn{9}{|c|}{ Production Centre } \\
\hline \multicolumn{2}{|l|}{ 5' Screen } & \multicolumn{2}{|l|}{ not attempted } & LoxP Screen & pass & \multicolumn{2}{|c|}{ 3' Screen } & pass \\
\hline \multicolumn{2}{|c|}{ Loss of WT Allele (LOA) } & \multicolumn{2}{|l|}{ - } & Vector Integrity & - & & & \\
\hline
\end{tabular}

Fig. 2.

Summary information for Chd4 knockout-first targeted clones. The IKMC webportal (www.knockoutmouse.org/martsearch) displays the current status of genes assigned to individual targeting pipelines with order links for vectors, targeted ES cell clones and mutant mice available from affiliated repositories. Links to detailed molecular information are provided, including annotated sequences (genbank files) and maps (allele images) of the targeted alleles. Gene-specific primers used for long-range PCR genotyping can be found by following the 'Design ID' link. 

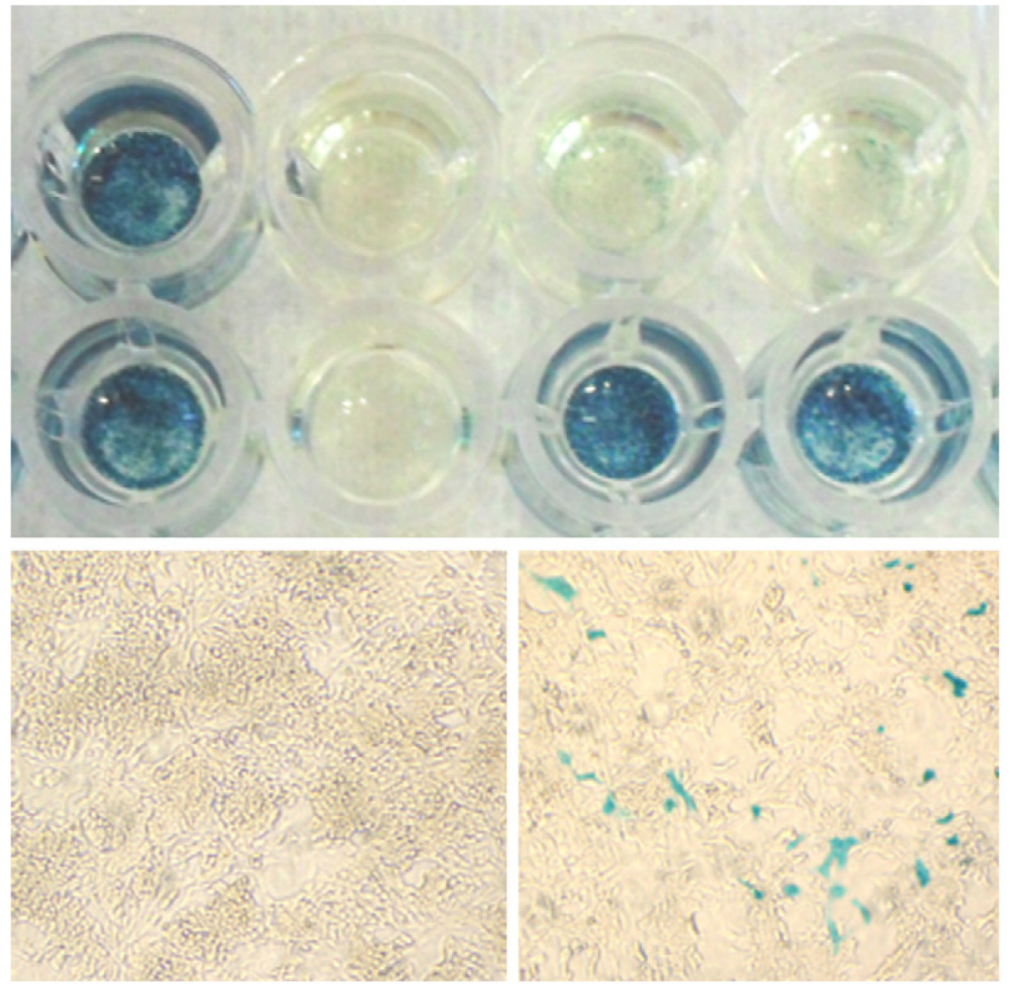

Fig. 3.

LacZ staining of Flp-treated ES cell clones. X-gal staining of expanded clones after transient transfection of $C h d 4$ knockout-first cells with Flp recombinase. A complete loss of $\beta$ galactosidase expression is observed in most clones (top and bottom left panels). Contamination of LacZ-positive cells can be detected in some of the wells (bottom right panel). 


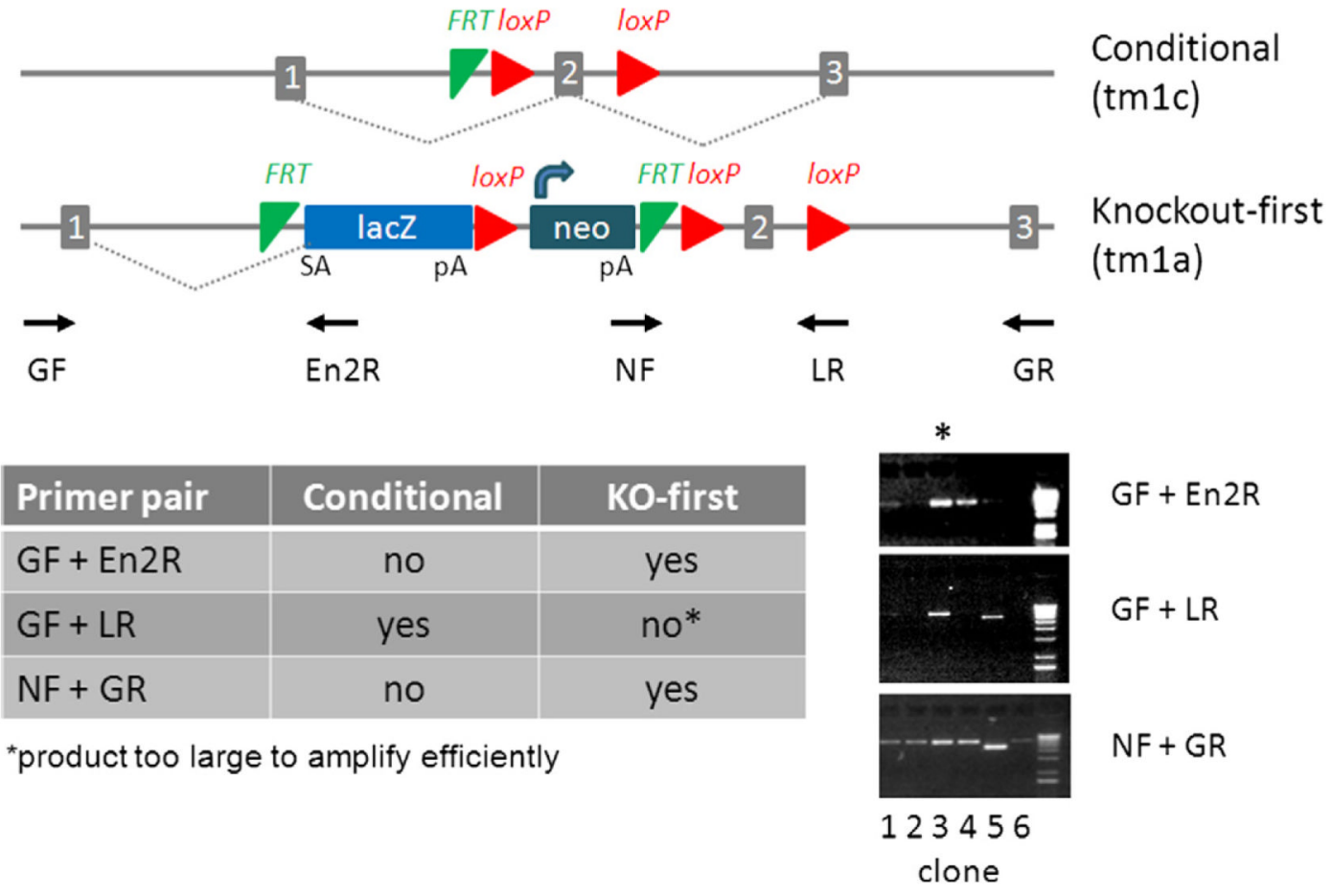

Fig. 4.

Identification of bi-allelic targeted clones by long-range PCR. The knockout-first allele is detected with a gene-specific primers outside of the $5^{\prime}$ homology (GF) and $3^{\prime}$ homology (GR) arms in combination with vector-specific primers to the En2 splice acceptor (En2R) and neo gene (NF), respectively. The conditional allele, but not the knockout-first allele is detected with GF and a primer to the $3 \times \operatorname{lox} P$ site (LR). The knockout-first allele is $>5 \mathrm{~kb}$ larger than the conditional allele, too large to be amplified with the GF/LR primer pair. In this example, clone 3 is positive for the knockout-first and conditional allele, indicating biallelic targeting. Clones 1 and 4 have re-targeted the conditional allele. The size of the amplified product in clone 5 is smaller than expected, suggesting a deletion has occurred in the locus. 


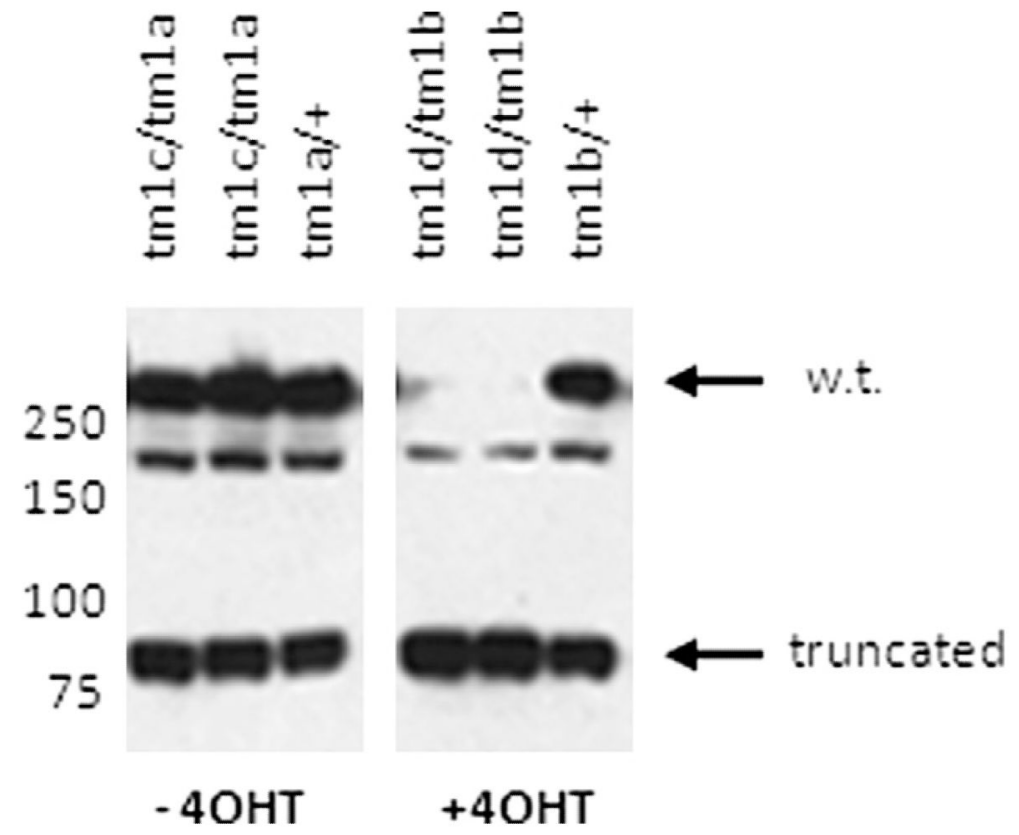

Fig. 5.

Tamoxifen-induced ablation of $C h d 4$ protein expression. Western blot of two Chd4 bi-allelic targeted clones (tm1c/tm1a) and a heterozygous targeted clone (tm1a/+) after two passages following treatment with ethanol $(-4 \mathrm{OHT})$ and tamoxifen $(+4 \mathrm{OHT})$. Activation of Cre recombinase in homozygous targeted clones removes the critical exon from the conditional targeted allele (tm1c) to generate the deletion allele (tm1d), eliminating expression of wildtype $C h d 4$ protein (w.t.). The $C h d 4$ antibody (Bethyl Laboratories A301-081A) also detects truncated $C h d 4$ protein expressed from the tm $1 \mathrm{a}$ and tm $1 \mathrm{~b}$ alleles. 